\title{
LETTERS OF AVIATION PIONEERS
}

[The Society has recently acquired four interesting letters-one from the late Mr. Wilbur Wright, two from Wilbur and Orville Wright, and one from the late Professor S. P. Langley. As it is thought these letters will be of interest to members, copies of them are printed below. The letter from the late $\mathrm{Mr}$. Wilbur Wright is particularly interesting both for its brief account of the work of himself and his brother and for the reference to Professor Langley. All the Wright letters are interesting in the way they throw a light on the characters of the two brothers, showing their willingness to give information of their work.EDITOR.]

COPY.

(Estabd. 1892) "Wright Cycle Co.," I 127 , West 3rd St., Dayton, Ohio. Mr. Sidney H. Hollands. July I6th, I905. Dear Sir,

We have received your letter with much pleasure.

Our experiments were continued during a considerable part of the summer and autumn of last year with quite favourable results.

It is not our desire, however, that too much interest in our work should be publicly aroused at present, and accordingly cannot make any extended report until the experimental period is past. In I9O4 we succeeded for the first time in making complete circles, and landing at the starting point.

On two different occasions the flight extended over nearly four rounds of the field, a distance of nearly three miles. The duration of the flight was five minutes and four seconds in one case, and four minutes and fifty seconds in the other. The speed was about 35 miles per hour. The new problems-previously unsuspected-which are met at almost every step consume much time in developing a machine for practical use, but the critical points have been passed, and within a reasonable time we expect to have the machine ready to present to the world for some serviceable purpose.

The articles in Flying were read at the time with interest, and it would please us to see some experiments along that line, to see whether it would offer any advantages over gliding as a method of practice. We hear from Mr. Chanute now and then, and at last report he was well, though he had a troublesome attack of the influenza last winter.

You have probably seen some account of the experiments which Mr. Avery made with a Chanute glider at St. Louis last summer. We have no recent word regarding Prof. Langley, but think he has abandoned the effort to fly his machine. It was evidently too frail to be of real value for experimental purposes. There is much more interest taken in aviation than for some years past, and, except the experiments of Mr. Montgomery, little of the work is of much value.

Yours truly,

(Signed) WILBUR WRIGHT, 